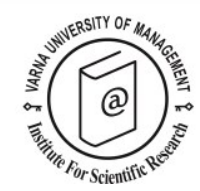

\title{
Peace and quiet beyond the border: the trans-border mobility of Russian second home owners in Finland
}

\author{
Olga Hannonen ${ }^{1}$
}

Received: 29/03/2017

\begin{abstract}
${ }^{1}$ Post-doctoral researcher, Karelian Institute, University of Eastern Finland, P.O. Box 111, Joensuu, FI-80101, Finland
\end{abstract}

Supervisors: Dr. Paul Fryer and Prof. Antti Honkanen

Institution awarding the Ph. D. Degree: University of Eastern Finland

Date of defence: 03/06/2016

(C) 2017 Varna University of Management. All rights reserved

Citation: Hannonen, O. (2016) Peace and quiet beyond the border: the trans-border mobility of Russian second home owners in Finland. Doctoral Dissertation Summary. European Journal of Tourism Research 17, pp. 261-264

\section{Goal and objectives of the dissertation Goal}

The doctoral dissertation focuses on Russian trans-border second home ownership in Finland. It is the first study on foreign property purchases in Finland and on Russian purchases abroad. The research case of Russian second home mobility to Finland along the East-to-West continuum deviates from the established (Western) viewpoints on leisure and mobility patterns. The aim of this work is to reveal the way that East-to-West trans-border second home mobility is produced, challenged, and its socio-economic and spatial outcomes at the local level. The study addresses the following questions:

1. What are the motives for Russian trans-border second home mobility?

2. What is the role of the border in Russian trans-border second home mobility?

3. How does trans-border second home mobility resonate at the local community level?
4. How are Russian second homes regionally distributed and which factors influence their distributional patterns?

Each research question is addressed in an individual research paper that comprise the empirical part of the dissertation.

\section{Methodology}

The study was carried out in the most popular region for Russian property purchases, the Savonlinna region and the region of South Savo in Eastern Finland. The data for the dissertation consists of three parts. First, interviews with Russian second home owners $(\mathrm{N}=25)$, conducted in summer and early autumn 2010 in the Savonlinna region in the region of South Savo in Eastern Finland. There was no selection technique for respondents as all participants, who had been reached one way or another, were interviewed. Second, questionnaires with Finnish local inhabitants $(\mathrm{N}=186)$ and second 
home owners $(\mathrm{N}=308)$, collected in summer 2010 in the same region. Third, coordinates on Russian second home locations in the region of South Savo in the period of 20032012 that were supported by other geographical databases with information on housing, residential areas, and terrain. The diversity of research material and methods of data collection and analyses provided an excellent opportunity to study the phenomenon from different perspectives.

\section{Results}

The empirical part of the dissertation consists of four research papers. The first paper (Lipkina, 2013) concerns the production of trans-border second home mobilities: Russian motives for second home ownership and location in Finland. The results show that the underlying motivations of second home purchase become more complex when applied to a trans-border context. Russians' motives are culturally driven, and influenced by the image of and previous experiences in Finland. Among the main motives are safety, both in term of physical safety and safety of investment, natural amenities, lower property prices and lakeshore ownership, which is restricted in Russia by law. Second home tourism is a popular recreation practice among Russians, but the decision to purchase a second home abroad is driven by differences in cultural, political and leisure conditions between Finland and Russia. Safety is a novel motive for second home ownership that has not been reported by other studies on trans-border or international second home ownership. Moreover, Russian second home location in Finland is not significantly dependent on time and distance. Only the distance to a second home from the border on the Finnish side is distance sensitive, not the overall trip from their primary residence. Particular location of Russian second homes in Finland is the result of offers from real estate agents.

The second paper (Hannonen, Tuulentie \& Pitkänen, 2015) investigates the role of the border in trans-border second home ownership. This subject has not received much academic attention. The border is, however, an essential component of second home ownership abroad: it is constantly crossed on the way to and from a second home, it marks the different regulations and norms that exist on either side, and imposes restrictions that shape mobility across it. The findings show that despite a strict border regimes and border formalities, the invisible barriers (socio-cultural and linguistic differences) are perceived by Russian second home owners as the most challenging. They influence second home owners' leisure activities in Finland leading to the formation of mediator-practices to fulfil their needs. The border also appears to be an opportunity for better leisure conditions, safety or lower property prices. While the border channels mobility, Russian second home ownership in Finland is the result of the very presence of the border due to the opportunities that are provided and safeguarded across it. These opportunities outweigh the barrier function of the border.

The third paper (Lipkina \& Hall, 2013) outlines the socio-economic outcomes of trans-border second home mobility from a community perspective: the community involvement of Russian owners, and their potential for economic impact. The paper brings together opinions and attitudes of both sides of community inhabitants, Russians and Finns. Language and cultural barriers appear to be the major obstacles for active community involvement by Russian owners. Thus, they have very limited social contacts in Finland even with fellow nationals. Russians, however, desire to be better integrated in the community. The language barrier and limited knowledge about the locality leads to the use of very basic services by Russians, which keeps the economic impact below their potential. The use of specialised services is managed through unofficial personal networks of help from neighbours or house builders. This relegates the economic contribution to initial property investment and compulsory payments to the local economy. Such limited socio-economic involvement is accompanied by a low level of acceptance from the receiving community. The majority of Finnish respondents in the region do not want 
to have contacts with Russian owners and have unfavourable views of Russian potential for community development. The study demonstrates the opposite expectations and attitudes of Finns and Russians towards each other, as well as the absence of knowledge about these contrasting attitudes.

The fourth paper (Hannonen, Lehtonen \& Toivakka, 2016) studies the spatial outcome of trans-border second home ownership: the factors for property location, and the interrelation between the critical social debate on Russian property locations and the distribution of Russian properties in the region of South Savo. The results provide a wider array of factors for property distribution than those presented in public debates. First, distance to and accessibility of a destination directly impact the distribution of recreational properties. Thus, Russian second homes are predominantly found in the more accessible border regions of two neighbouring countries. Second, the amenities of a destination, a lakeside location in this case, is another important factor. Third, the presence of services is also a significant component in trans-border ownership, as owners are limited in the amount of goods they may import due to border regulations. Moreover, the particular location of a second home, especially in foreign ownership, is often the result of real estate agents' offers. Any of these factors or a combination of them can lead to concentrations of foreign properties in particular areas. Consequently, Russian purchases have generally been dominant in the eastern part of South Savo over the last years.

\section{Theoretical conclusions}

Mobility is an overarching theoretical approach in the dissertation. To better understand trans-border second home mobilities the concept of "constellations of mobility" (Cresswell, 2010) and "mobility regime" (Shamir, 2005) have been employed.

The eight elements of "constellations of mobility" (Cresswell, 2010; Cresswell \& Martin, 2012; Vannini, 2011) help to explain the production of second home mobilities by unfolding the role of each component and its characteristics. The research case shows that constellations of mobility do not define the 'outcome' as a separate element that is integrally tied to second home mobilities, and do not explain the role of borders in the production of mobilities. The mobility approach defines the importance of borders for contemporary mobilities as means of control and surveillance of mobile populations, it does not consider borders as an important agent in producing mobilities. The doctoral study illustrates that, in addition to the barrier and control function, the border produces various interactions across it, which would not exist without the border. For Russians the border is a mark of positive differences, an opportunity to have a desirable safe leisure environment. The study also shows that 'outcome', as a social, economic or spatial impact, as well as the opposition to foreign property ownership is an inseparable element of mobility, which should be defined as a separate component in mobility constellations.

The Finnish-Russian border manifests a particular mobility regime between the two states. The present research case differs from second home mobility across internal EU (European Union) borders. The FinnishRussian border is a heavily guarded external border of the EU that marks one of the highest economic differences in the world between neighbouring countries, as well as cultural and linguistic disparities. The study shows that the increasing mobility of people from different parts of the world demands a re-conceptualisation of the established patterns and approaches to mobility developed in the West (Cohen \& Cohen, 2015). It deviates from the established trajectories of leisure flows in the West, such as North-to-South and West-to-East vectors, and represents the East-to-West leisure mobility vector. The dissertation represent an attempt to explain and theorise Russian second home mobility across the FinnishRussian border as a new type of East-to-West leisure mobility.

\section{Practical application of the dissertation}

Russian property purchases in Finland have been followed by a contested social debate 
with predominantly negative estimations of the phenomenon. In this regard, findings of the study are of special societal importance for Finland. As the first study on Russian property purchases in Finland, the dissertation provides the first-hand information about Russian second home ownership. It uncovers the driving factors in Russian second home mobility, its challenges, socio-economic outcome and regional distribution, which collectively address the social debate on the phenomenon and inform policy makers.

The Finnish public debate on Russian property purchases has proven to be detached from the actual Russian motivations (Lipkina, 2013), local relations (Lipkina \& Hall, 2013) and factors for property location (Hannonen, Lehtonen \& Toivakka, 2016). This is an important societal knowledge that dispels some stereotypes and prejudices about the phenomenon. The limited participation in the local community that leads to the formation of mediator practices should be further practically addressed, as they have potential for local businesses to develop their services.

Russians are one of the biggest clients' groups of the world's tourism industry. Their views on recreation contrast those elaborated in the West. Thus, the present research significantly contributes to understanding the needs, motivations and priorities of Russian property owners and their mobility patterns.

\section{References:}

Cohen, E. \& Cohen S.A. (2015). Beyond Eurocentrism in Tourism: A Paradigm Shift to Mobilities. Tourism Recreation Research, 40 (2), 157-168.
Cresswell, T. (2010). Towards a politics of mobility. Environment and Planning $D$ : Society and Space, 28, 17-31.

Cresswell, T. \& Martin, C. (2012). On Turbulence: Entanglements of Disorder and Order on a Devon Beach. Tijdschrift voor Economische en Sociale Geografie, 103 (5), 516-529.

Hannonen, O., Lehtonen, O. \& Toivakka, M. (2016). Confronting the social debate: A study of the distribution of Russian recreational properties in Eastern Finland. Norsk Geografisk Tidsskrift Norwegian Journal of Geography 70 (2), 95-111.

Hannonen, O., Tuulentie, S. \& Pitkänen, K. (2015). Borders and second home tourism: Norwegian and Russian second home owners in Finnish border areas. Journal of Borderlands Studies, 30 (1), 53-67.

Lipkina, O. (2013). Motives for Russian second home ownership in Finland. Scandinavian Journal of Hospitality and Tourism, 13 (4), 299-316.

Lipkina, O. \& Hall, C. M. (2013). Russian second home owners in Eastern Finland: involvement in the local community. In M. Janoschka \& H. Haas (eds.) Contested Spatialities, Lifestyle Migration and Residential Tourism. Oxon: Routledge. 158-173.

Shamir, R. (2005). Without Borders? Notes on Globalization as a Mobility Regime. Sociological Theory, 23 (2), 198-217.

Vannini, P. (2011). Constellations of Ferry (Im)Mobility: Islandness as the Performance and Politics of Insulation and Isolation. Cultural Geographies, 18 (2), 249-271. 